О. Ю. Коцюрба, доц., канд. екон. наук

Д. С. Насипайко, канд. екон. наук, доц.

Центральноукрайнський наџіональний технічний університет, м. Кропивницький, Украйна

\title{
Страховий ринок України: сучасний стан та проблеми розвитку
}

Статтю присвячено дослідженню особливостей функціонування страхового ринку України в сучасних умовах виникнення нових непередбачених загроз та викликів. Проаналізовано сучасний стан національного страхового ринку та визначено основні тенденції його розвитку у 2017-2020 рр. 3’ясовано, що зміна основних показників страхового ринку України відбулась під впливом спаду економіки внаслідок поширення коронорвірусної хвороби. Визначено основні проблеми, які стримують розвиток національного страхового ринку, та вирішення яких забезпечить його становлення як драйвера економічного розвитку країни.

страховий ринок, страхові премії, страхові виплати, страхування, страхові компанії

О. Ю. Коцюрба, доц., канд. экон. наук

Д. С. Насыпайко, доц., канд. экон. наук

Центральноукраинский национальный технический университет, г. Кропивницкий, Украина

\section{Страховой рынок Украины: современное состояние и проблемы развития}

Статья посвящена исследованию особенностей функционирования страхового рынка Украины в современных условиях возникновения новых непредвиденных угроз и вызовов. Проанализировано современное состояние национального страхового рынка и определены основные тенденции его развития в 2017-2020 гг. Установлено, что изменение основных показателей страхового рынка Украины состоялась под влиянием спада экономики в результате распространения коронорвируснои болезни. Определены основные проблемы, сдерживающие развитие национального страхового рынка, и решение которых обеспечит его становление как драйвера экономического развития страны.

страховой рынок, страховые премии, страховые выплаты, страхование, страховые компании

Постановка проблеми. В сучасних умовах економічний розвиток супроводжується ризиками ендогенного та екзогенного характеру. Запобігання виникнення даних ризиків або їх мінімізація забезпечується за допомогою страхування, яке покликане захищати майнові інтереси фізичних та юридичних осіб у разі настання певних несприятливих подій через відшкодування понесених ними збитків.

До того ж страхування виступає важливим джерелом акумуляції коштів, які находять у вигляді страхових премій з подальшим їх перетворенням у довгострокові інвестиції в розвиток національної економіки. За допомогою страхування забезпечується й зменшення навантаження на державний бюджет в частині відшкодування збитків, спричинених внаслідок надзвичайних ситуацій, катастроф, катаклізмів, різноманітних природних лих, а також захист бізнесу від непередбачуваних ризиків та забезпечується соціальна підтримка громадян [3].

В динамічних умовах інтеграції України в Європейське Співтовариство, мінливості економічного середовища, активізації процесів глобалізації постає необхідність дослідження проблем функціонування страхового ринку та знаходження перспективних напрямів його розвитку.

Аналіз останніх досліджень і публікацій. Сучасний стан та проблеми розвитку страхового ринку України досліджується багатьма вченими та економістами. Так, вчені Н. Фесенко та Л. Яремченко зосереджують свою увагу на питаннях глобалізації страхового ринку України та проблем з цим пов'язаних [11]. О. Руда наголошує на

(с) О. Ю. Коцюрба, Д. С. Насипайко, 2020 
необхідності ефективного регулювання страхового ринку та формуванні стратегії його розвитку [9]. В. Плиса розглядає страховий ринок України в контексті його інвестиційної привабливості та відзначає необхідність формування операційного потенціалу страхового ринку в Україні [6]. Ю. Заволока, А. Єфременко, Ю. Малашенко дослідили використання цифрових та інтернет-технологій в страховій галузі, що розкривають нові можливості в страхуванні як для страховиків, так $\mathrm{i}$ для страхувальників [1]. Дослідження Д. Коваленко зосереджене на розвитку пруденційного регулювання страхового ринку в Україні на основі прийняття довгострокової стратегії розвитку страхового ринку як складової пруденційної політики, визначенні системоутворюючих страховиків та посиленні незалежності регулятора [4]. А. Горлач розглянув фінансову стійкість страхового ринку, виокремив чинники впливу та основні критерії ії забезпечення [2].

Не зважаючи на велику кількість досліджень вчених з питань функціонування страхового ринку України, питання нових тенденцій та проблем розвитку страхового ринку України потребують подальшого вивчення.

Постановка завдання. Метою статті є дослідження функціонування страхового ринку України, визначення сучасних тенденцій та проблем розвитку з урахуванням нових економічних викликів.

Виклад основного матеріалу. Складовою фінансової системи будь-якої держави є страховий ринок, основним призначенням якого виступає забезпечення майнового захисту інтересів населення, юридичних осіб та держави. Ефективність його функціонування являється відображенням рівня загальноекономічної ситуації в країні та регулювання державою.

Страховий ринок України являється одним із найперспективніших із точки зору потенціалу розвитку. Однак в Україні страхуванням охоплено менш ніж 10-15\% страхового поля, в той час як у країнах Західної Свропи - більш ніж 94\% [7, с. 815].

В сучасній економічній літературі представлені різноманітні підходи до визначення сукупності факторів, що стримують розвиток страхового ринку України. Так, наприклад, виділяють фактори нормативно-правового, економічного, інформаційного та соціального характеру. Тому аналіз основних показників національного страхового ринку дозволить визначити «вузькі» місця його функціонування та окреслити перспективи його подальшого розвитку з урахуванням сучасних загальноекономічних тенденцій.

Протягом 2017-2020 рр. на страховому ринку країни мало місце зменшення кількості страхових компаній та кількості укладених договорів, що $є$ наслідком загальної економічної нестабільності в державі та зниженням динаміки розвитку страховому ринку. 3 табл. 1 можна побачити, що у III кварталі 2020 р. на ринку функціонувало 215 страховиків, 3 яких 20 страховиків зі страхування життя та 195 страховиків з ризикового страхування або 9,3 і 90,7 \% відповідно. Тоді як у III кварталі 2017 року загальна кількість страховиків на ринку складала 296, з яких 34 страховики зі страхування життя та 262 страховиків з ризикового страхування або 11,5 і 88,5\% відповідно. Подібна тенденція мала місце і стосовно кількості укладених договорів страхування, так якщо у III кв. 2017 року було укладено 136344,3 тис. договорів, то у III кв. 2020 р. їх кількість зменшилась до 89434,5 тис. шт. 
Таблиця 1 - Показники страхового ринку України в III кв. 2017-III кв. 2020 pp.

\begin{tabular}{|c|c|c|c|c|}
\hline \multirow{2}{*}{ Показники } & \multicolumn{4}{|c|}{ Період } \\
\hline & III кв. 2017 & III кв. 2018 & III кв. 2019 & III кв. 2020 \\
\hline $\begin{array}{l}\text { Кількість } \\
\text { страховиків, з них: }\end{array}$ & 296 & 285 & 234 & 215 \\
\hline компанії зі страхування життя & 34 & 31 & 26 & 20 \\
\hline $\begin{array}{l}\text { компанії, що здійснюють страху- } \\
\text { вання інше ніж страхування життя }\end{array}$ & 262 & 254 & 208 & 195 \\
\hline $\begin{array}{l}\text { Кількість у укладених } \\
\text { страхування (тис. од.) }\end{array}$ & 136344,3 & 153312,5 & 149589,2 & 89434,5 \\
\hline Загальні активи, млн. грн. & 56813,8 & 59468,2 & 66950,6 & 61626,35 \\
\hline Величина страхових резервів, млн. грн. & 21804,8 & 24833,2 & 29661,3 & 29614,85 \\
\hline
\end{tabular}

Така ситуація пояснюється загальним погіршенням соціально-економічного стану в державі та тісною залежністю від цього національного страхового ринку.

Особливістю фінансів страхових компаній є виокремлення у залученому капіталі страхових резервів. Необхідність формування страхових резервів визначається імовірнісним характером страхових подій, невизначеністю часу настання та величини збитку.

Страхові резерви - величина, яка визначає грошову оцінку зобов'язань страховика за договорами страхування (перестрахування), розрахована відповідно до вимог законодавства 3 метою забезпечення майбутніх страхових виплат залежно від видів страхування [8].

Страхові резерви у III кв. 2020 р. зросли порівняно 3 III кв. 2017 р. на 7810,05 млн. грн. внаслідок зростання зобов'язань страхових компаній, що мають забезпечуватись відповідним обсягом страхових резервів.

В період 3 III кв. 2017 р. до III кв. 2019 р. обсяги валових страхових премій відзначалися нарощенням з 31391,1 до 40561,9 млн. грн., а у III кв. 2020 р. мало місце зменшення обсягів до 32967,1 млн. грн. (рис. 1).

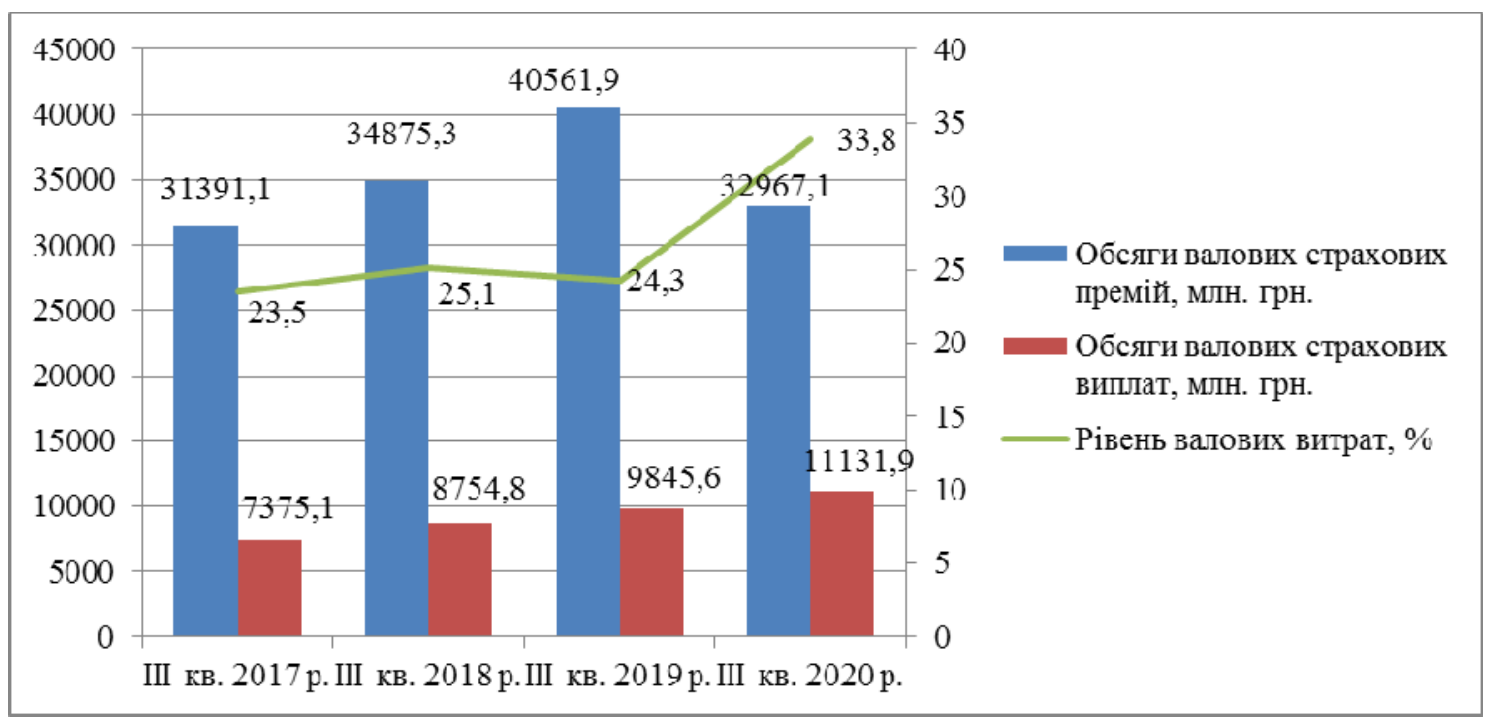

Рисунок 1 - Динаміка обсягів страхових премій та виплат, рівня валових страхових виплат за III кв. 2017 р.- III кв. 2020 р.

Джерело: складено авторами за даними [10] 
Причиною цього стало розповсюдження пандемії та запровадження на державному рівні обмежуючих карантинних заходів, що суттєво знизило фінансові можливості потенційних клієнтів страхових компаній.

Аналіз динаміки валових страхових виплат навпаки засвідчив зростання їх обсягів 3 7375,1 млн. грн. у III кв. 2017 р. до 11131,9 млн. грн. у III кв. 2020 р., що відбулось внаслідок збільшення кількості настання страхових випадків, які були передбачені в укладених договорах страхування. Це $є$ підтвердженням важливості страхування як засобу зниження ризиків.

Зростанням відзначається i рівень валових страхових виплат страхових компаній, так якщо у III кв. 2017 р. він склав 23,5 \%, то у III кв. 2020 р. - вже 33,8 \%. Відповідно до досліджень науковців прийнятним вважається рівень валових виплат до 40\%. Тобто страховики в Україні на кінець 2020 р. внаслідок фінансової нестабільності наблизились до критичної межі рівня валових виплат.

Структура валових страхових премій та валових страхових виплат відзначається своєю нерівномірністю (рис. 2, 3).

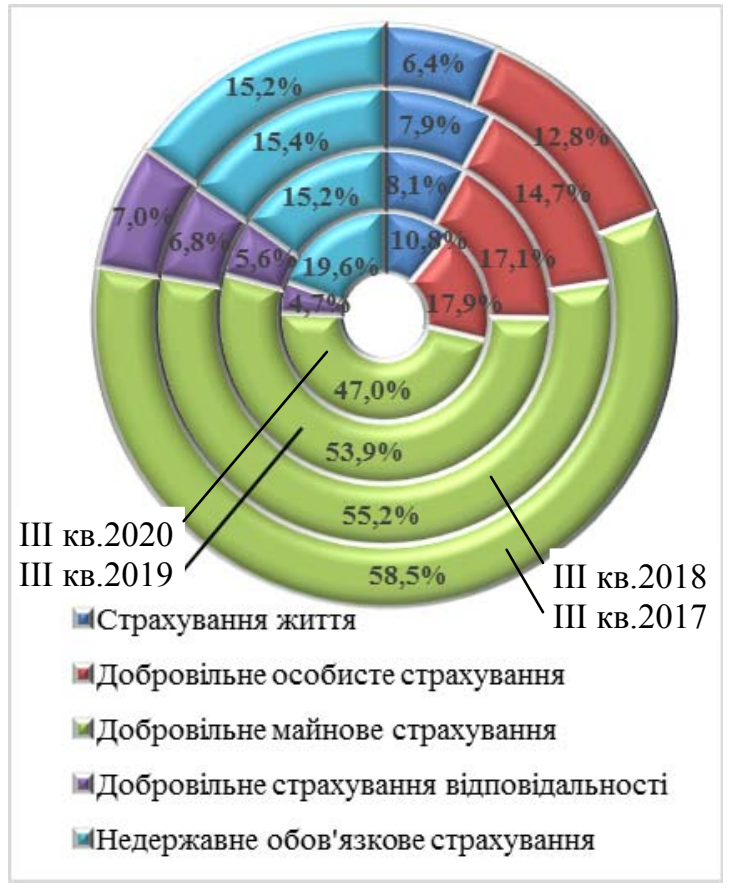

Рисунок 2 - Структура валових страхових премій у III кв. 2017 р.- III кв. 2020 р.

Джерело: складено авторами за даними [10]

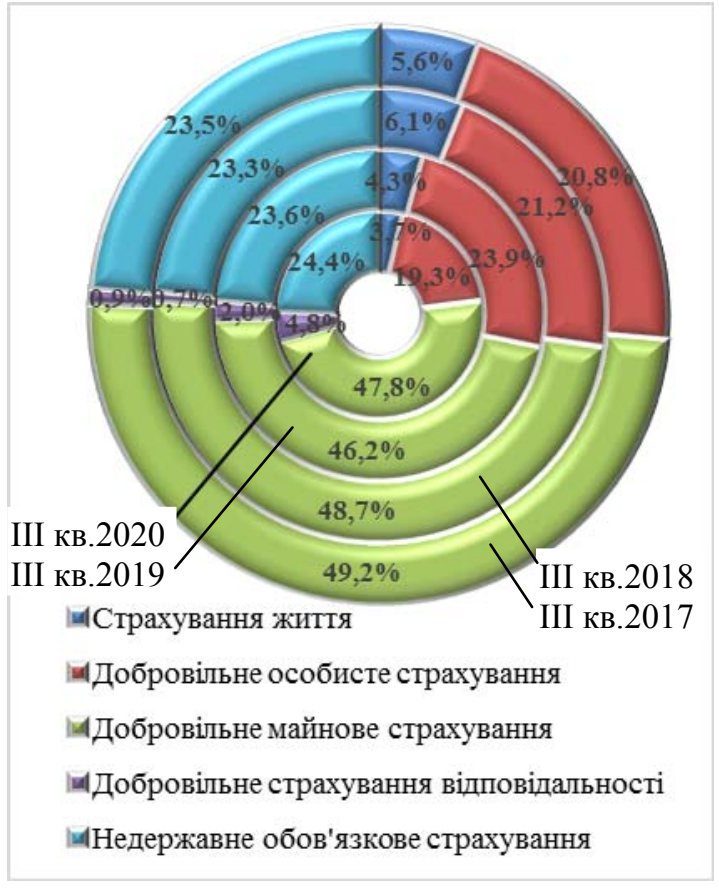

Рисунок 3 - Структура валових страхових виплат у III кв. 2017 р.- III кв. 2020 p.

Важливим індикатором розвитку страхових компаній є кількість укладених ними страхових договорів. Оцінюючи наявну динаміку, бачимо збільшення їх кількості лише у III кв. 2018 р. до 153312,5 тис. од. 3 послідуючим зменшенням до 89434,5 тис. од. у ІІІ кв. 2020 р., при чому зменшення відбулось за договорами зі страхування життя та обов'язкового страхування.

На макроекономічному рівні основним показником розвитку страхового ринку являється частка валових страхових премій у відношенні до ВВП (показник проникнення страхування). Для страхового ринку України характерним є не тільки наднизький їі рівень, але й перманентне зменшення (рис. 4). Так, якщо у 2017 р. даний показник 1,5 \%, то у 2020 р. - вже 1,1 \%. Однак вважається, що страховий ринок $\epsilon$ 
ефективним при значенні цього показника на рівні не менше, ніж 7 \% [5, с. 263]. Наприклад, у Фінляндії ця частка складає 11,8 \%, у Франції - 9,7 \%, а у США - 7,3 \% [9]. Тобто, очевидними є кризові явища на національному страховому ринку.

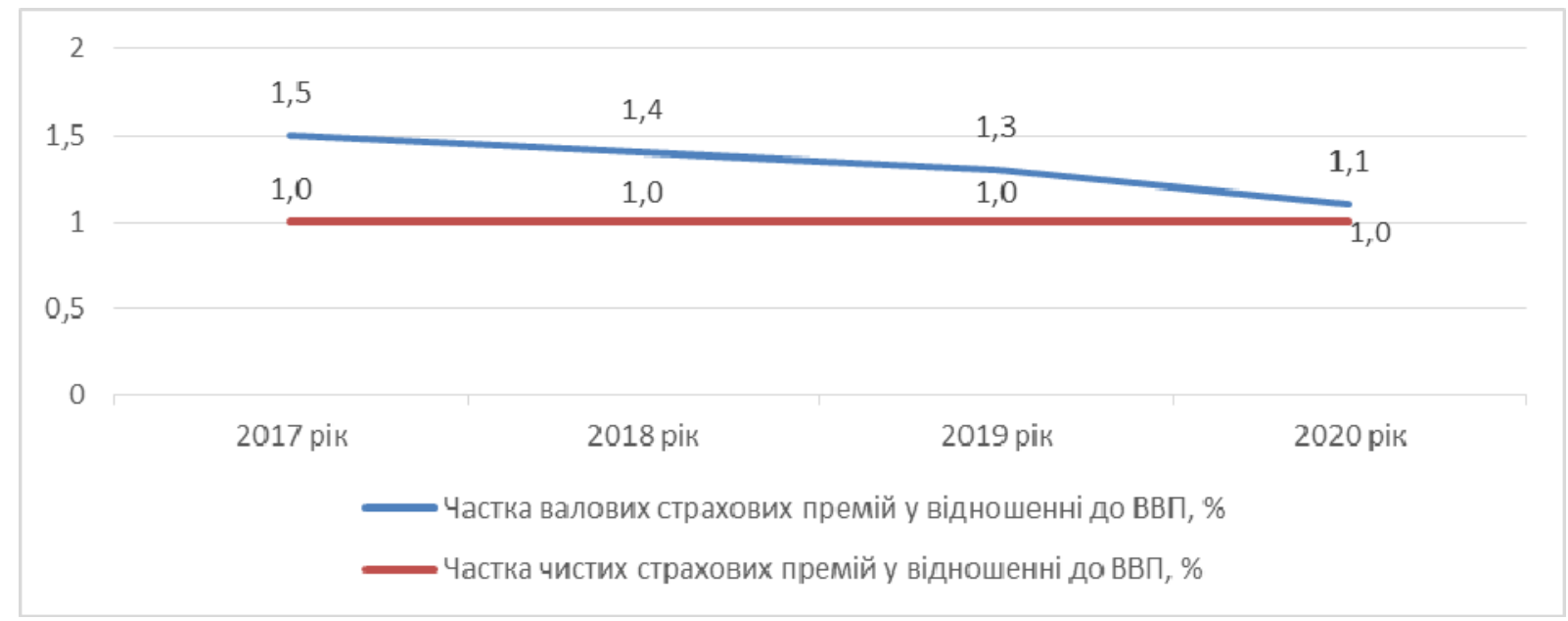

Рисунок 4 - Динаміка показника проникнення страхування у 2017-2020 p

Джерело: складено авторами за даними [10]

В сучасних умовах основними проблемами розвитку страхового ринку України являються наступні:

- відсутність єдиної державної стратегії розвитку національного страхового ринку, зміна регулятора i, відповідно, загальних бачень розвитку національного страхового ринку його представниками;

- недосконалість та фрагментарність нормативно-правової бази у сфері страхування;

- погіршення економічної та політичної ситуації в країні;

- низький рівень якості страхових послуг, які надаються окремими страховими компаніями, та страхової культури учасників страхового ринку;

- нерозвиненість фінансового ринку та брак ліквідних та надійних фінансових інструментів для інвестування ресурсів страхових компаній;

- страхове шахрайство;

- слабкі зовнішньоекономічні зв'язки України у сфері страхування з іншими країнами [11, с. 31$]$;

- низький рівень впровадження інновацій страховиками;

- неналежний рівень інформаційної відкритості страхового ринку та ін.

Усунення зазначених вище проблем дасть можливість сформувати ефективний, розвинений страховий ринок, який в сучасних умовах може стати не просто драйвером розвитку фінансового ринку, а й національної економіки та сприяти підвищенню фінансово-економічної безпеки країни.

Висновки та перспективи подальших досліджень. Підсумовуючи викладене вище, слід відмітити, що Україна за рівнем розвитку страхового ринку значно поступається країнам Європи. Головною передумовою цього стало погіршення економічної ситуації в країні, що відбулось під впливом окупації Російською Федерацією Криму, проведення з 2014 року антитерористичної операції та операції Об’єднаних Сил на сході країни, а ще й до того поширення з кінця 2019 року пандемії коронорвірусної хвороби у всьому світі, що стало справжнім випробуванням на міцність для економік всіх без виключення країн світу. Проведений аналіз засвідчив, 
що якщо до 2020 року на національному страховому ринку відмічався незначний, але сталий розвиток, то з 2020 року на нього суттєво вплинули обмежуючі карантинні заходи на рівні держави і обсяги валових страхових премій впали одразу на 19 \% в порівнянні з 2019 роком. Але, з іншої сторони, карантин виступив «прискорювачем» цифрової трансформації сфери страхування та появи на українському ринку нових страхових продуктів, таких як: кібер-страхування, Р2Р-страхування і мікрострахування, блокчейн і смартконтракти у страхуванні, insuretech, які вже певний час успішно реалізуються в зарубіжній страховій практиці. Перспективами подальших досліджень у даному напрямі $є$ визначення стратегічних орієнтирів та формулювання тактичних заходів розвитку національного страхового ринку в умовах постійного виникнення нових загроз та викликів.

\section{Список літератури}

1. Заволока Ю., Єфременко А., Малашенко Ю. Особливості функціонування страхового ринку України в умовах сучасної цифрової трансформації. Економіка та держава. 2020. № 6. С. 102-106.

2. Горлач A. С. Фінансова стійкість страхового ринку України. URL: http://nu.edu.ua/sites/default/files/normativbasa/materkonf2122020.pdf\#page=164 (дата звернення: 14.09.2020).

3. Клепікова О. А. Дослідження динаміки розвитку страхового ринку України як складової світового ринку страхових послуг. Вісник Одеського національного університету. Економіка. 2010. Т. 15. Вип. 20. С. 101-111.

4. Коваленко Д. П. Розвиток пруденційного регулювання страхового ринку в Україні : дис. ... канд. екон. наук : 08.00.08. Чернігів, 2020. 179 с.

5. Левченко В. Проблеми та перспективи розвитку страхового ринку України в умовах фінансової нестабільності. Збірник наукових праџь Національного університету державної податкової служби Украӥни. 2011. № 1. С. 257-266.

6. Плиса В. Інвестиційна привабливість страхового ринку України. Розвиток обліку, аудиту та оподаткування в умовах інноваційної трансформації соціально-економічних систем: Матеріали VIII Міжнародної науково-практичної конференції, 25 листопада 2020 р. Кропивницький: Ексклюзив-Систем, 2020. 404 с.

7. Пономарьова О. Б. Визначення проблем страхового ринку та їх вирішення. Глобальні та національні проблеми економіки. 2015. Випуск 5. С. 814-817.

8. Про затвердження Положення про обов'язкові критерії і нормативи достатності капіталу та платоспроможності, ліквідності, прибутковості, якості активів та ризиковості операцій страховика: Розпорядження Національної комісії, що здійснює державне регулювання у сфері ринків

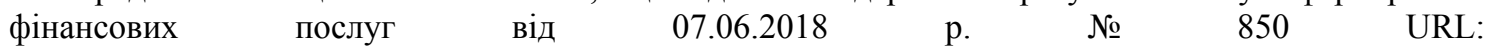
https://zakon.rada.gov.ua/laws/show/z078218/ed20180607\#n38 (дата звернення: 14.09.2020).

9. Руда О. Л. Розвиток страхового ринку в Україні. Ефективна економіка. 2020. № 2. URL: http://socrates.vsau.org/repository/getfile.php/24613.pdf (дата звернення: 14.09.2020).

10. Статистика страхового рынка Украины. URL: https:/forinsurer.com/stat (дата звернення: 14.09.2020).

11. Фесенко Н. В., Яремченко Л. М. Стан та перспективи функціонування страхового ринку України в умовах глобалізації. Економіка та держава. 2019. № 8. С. 28-34.

\section{References}

1. Zavoloka, Yu., Yefremenko, A., Malashenko, Yu. (2020). Osoblyvosti funktsionuvannia strakhovoho rynku Ukrainy v umovakh suchasnoi tsyfrovoi transformatsii [Features of the functioning of the Ukraine' insurance market in modern digital transformation conditions]. Ekonomika ta derzhava - Economy and State, 6, 102-106 [in Ukrainian].

2. Horlach, A. S. (2020). Finansova stiikist strakhovoho rynku Ukrainy. [Financial stability of the Ukraine' insurance market]. tnu.edu.ua. Retrieved from http://tnu.edu.ua/sites/default/files/normativbasa/materkonf2122020.pdf\#page=164 [in Ukrainian].

3. Klepikova, O. A. (2010). Doslidzhennia dynamiky rozvytku strakhovoho rynku Ukrainy yak skladovoi svitovoho rynku strakhovykh posluh. [Investigation of the development' dynamics of the Ukraine' insurance market as a component of the insurance services' global market]. Visnyk Odeskoho 
natsionalnoho universytetu. Ekonomika - Bulletin of the Odessa National University. Economics, T. 15, V. 20, 101-111 [in Ukrainian].

4. Kovalenko, D. P. (2020). Rozvytok prudentsiinoho rehuliuvannia strakhovoho rynku v Ukraini [Prudential regulation' development of the insurance market in Ukraine]. Candidate's thesis. Chernihiv: Chernihiv National Technological University [in Ukrainian].

5. Levchenko, V. (2011). Problemy ta perspektyvy rozvytku strakhovoho rynku Ukrainy v umovakh finansovoi nestabilnosti [Problems and prospects for the development of the Ukraine' insurance market in conditions of financial instability]. Zbirnyk naukovykh prats Natsionalnoho universytetu derzhavnoi podatkovoi sluzhby Ukrainy - Scientific works' collection of the National University of Ukraine' State Tax Service, 1, 257-266 [in Ukrainian].

6. Plysa, V. (2020). Investytsiina pryvablyvist strakhovoho rynku Ukrainy [Investment attractiveness of the Ukraine' insurance market]. Development of accounting, audit, and taxation in the conditions of innovative transformation of socio-economic systems: VIII Mizhnarodna naukovo-praktychna konferentsia (25 lystopada 2020 r.) - International Scientific and Practical Conference (p. 102), Kropyvnytskyi, Exclusive-System [in Ukrainian].

7. Ponomarova, O. B. (2015). Vyznachennia problem strakhovoho rynku ta yikh vyrishennia [Determination of the insurance market' problems and their solution]. Hlobalni ta natsionalni problemy ekonomiky Global and National Problems of Economy, 5, 814-817 [in Ukrainian].

8. Pro zatverdzhennia Polozhennia pro oboviazkovi kryterii i normatyvy dostatnosti kapitalu ta platospromozhnosti, likvidnosti, prybutkovosti, yakosti aktyviv ta ryzykovosti operatsii strakhovyka: Rozporiadzhennia Natsionalnoi komisii, shcho zdiisniuie derzhavne rehuliuvannia u sferi rynkiv finansovykh posluh vid 07.06.2018 r. № 850 [On approval of the Regulations on mandatory criteria and standards of capital adequacy and solvency, liquidity, profitability, quality assets and risks of operations of the insurer: the disposal of the National Commission, whic h carries out state regulation in the field of financial services markets from 07.06.2018 No. 850]. zakon.rada.gov.ua. Retrieved from https://zakon.rada.gov.ua/laws/show/z078218/ed20180607\#n38 [in Ukrainian].

9. Ruda, O. L. (2020). Rozvytok strakhovoho rynku v Ukraini [Development of the insurance market in Ukraine]. Efektyvna ekonomika - Effective economy, 2. Retrieved from http://socrates.vsau.org/repository/getfile.php/24613.pdf [in Ukrainian].

10. Statistika strakhovogo rynka Ukrainy [Statistics of the Ukraine' insurance market]. forinsurer.com. Retrieved from https://forinsurer.com/stat [in Russian].

11. Fesenko, N. V., Yaremchenko, L. M. (2019). Stan ta perspektyvy funktsionuvannia strakhovoho rynku Ukrainy $\mathrm{v}$ umovakh hlobalizatsii [The condition and prospects of the functioning of the Ukraine' insurance market in the conditions of globalization]. Ekonomika ta derzhava - Economy and State, 8, 2834 [in Ukrainian].

Olha Kotsiurba, Associate Professor, $\mathrm{PhD}$ in Economics (Candidate of Economic Sciences)

Daria Nasypaiko, $\mathrm{PhD}$ in Economics (Candidate of Economic Sciences)

Central Ukrainian National Technical University, Kropyvnytskyi, Ukraine

\section{Insurance Market of Ukraine: Current State and Development Problems}

The article is devoted to the study of the peculiarities of the Ukraine' insurance market functioning in the modern conditions of emergence of new unforeseen threats and challenges.

The current state of the national insurance market is analyzed and the main trends of its development in 2017-2020 are identified. It was found that the change in the main indicators of the insurance market of Ukraine occurred under the influence of economic downturn due to the spread of coronary heart disease. Thus, if until 2020 the national insurance market was marked by insignificant but stable development, then from 2020 it was significantly affected by restrictive quarantine measures at the state level, which led to a sharp decrease of $19 \%$ in gross insurance premiums compared to 2019. There was a decrease in the number of insurers during the study period from 296 to 215 , with the largest decrease in the number of companies providing insurance other than life insurance. It is noted that the impetus for the national insurance market development will provide the sale of new insurance products, such as cyber-insurance, P2P insurance and microinsurance, blockchain and smart contracts in insurance, insuretech.

The main problems that hinder the development of the national insurance market are identified. These include: the lack of a unified state strategy for the development of the national insurance market, the change of the regulator and, accordingly, the general vision of the development of the national insurance market by its representatives; imperfection and fragmentation of the regulatory framework in the field of insurance; underdeveloped financial market and lack of liquid and reliable financial instruments for investing resources of insurance companies; fears of fraud; low level of innovation by insurers; improper level of information openness 
of the insurance market, etc. The solution of these problems will ensure its formation as a driver of economic development of the country.

insurance market, insurance premiums, insurance payments, insurance, insurance companies

Одержано (Received) 17.09.2020

Прорецензовано (Reviewed) 28.09.2020

Прийнято до друку (Approved) 21.12.2020 